\section{PP-037 経尿道的前立腺核出術（TUEB）の経験}

\section{川崎市立多摩病院泌尿器科}

古畑 壮一, 工藤 浩也, 山川 克典

【目的】前立腺肥大(以下 BPH) に対する低侵襲手術である、 バイポーラシステムを利用した経尿道的前立腺核出術 (transurethral enucleation with bipolar : 以下 TUEB)の経 験を報告する。【対象と方法】当科では TUEB を2008 年 3 月より導入し、2008 年 9 月までに 23 例の BPH 患者に対し て施行した。年齢は $61 \sim 81$ 歳(平均 68 歳) で、術前のPSA は $2.2 \sim 20 \mathrm{ng} / \mathrm{ml}$ (平均 $7.3 \mathrm{ng} / \mathrm{ml}$ ) で、 $4.0 \mathrm{ng} / \mathrm{ml}$ 以上の患者 においては術前に経直腸的前立腺生検を行い、癌を否定し ている。超音波検查で測定した前立腺の推定体積は 36.4 $124.6 \mathrm{ml}$ (平均 $74.1 \mathrm{ml}$ ) であった。[結果】当科はモルセレー ターが無いため、借用した 3 例以外はループ電極での細切 除去で行った。輸血を要した症例は無く、カテーテルは術 後2 5 日目に抜去した。TUEB の評価は術前、と術後 3 カ月目に自覚症状スコア、尿流量㧍よび残尿測定、PSA 測定にて行った。
PP-039

形状記憶合金製尿道ステント治療の適応 と限界
山形大学医学部代謝再生統御学講座腎泌尿器外科学分野

長岡 明, 富樫 素子, 䅡井 俊彦, 内藤 整, 柴崎 智宏,

川添 久, 山辺 拓也,ビリーム ウラジミル, 武藤 明紀, 加藤 智幸, 富田 善彦

【目的】手術困難な前立腺肥大症による尿閉症例に対する尿道ス テント留置術の治療成績を検討し、尿道ステント留置術の適応と 限界について検討する。【対象】2000年 7月より 2007 年 12 月の期 間に当科拈よび関連施設にて形状記憶合金製尿道ステント MEMOCATH を留置した男性尿閉症例 30 例に対し、IPSS、QOL、 残尿量、留置期間、合併症につき検討した。結果】平均年齢は $83.2 \pm 6.3$ 歳 $(67$ 歳 -93 歳)、前立腺重量は $71.6 \pm 44.3 \mathrm{~g}$ 、ステント長 は $5.7 \pm 1.5 \mathrm{~cm}(3-8)$ 、交換回数は $0.7 \pm 1.1$ 回 (0-4) であった。自覚 所見では IPSS、QOL ともに統計学的有意に改善したが、蓄尿症状 は不変ないし悪化した。他覚所見では 30 例中 27 例で自排尿可能 となり、残尿量は $14.1 \pm 16.5 \mathrm{ml}$ であった。平均留置期間は、21.1土 18.4 ケ月であった。合併症としては、結石形成 $60 \%$ 、膿尿 $64 \%$ 、 肉眼的血尿 $16 \%$ が代表的なものであった。考案】初回ステント 交換の多くが概ね 2 年以内に行われており、今回の検討では尿道 ステント留置術の期間は 2 年間が目安になると考えられた。ステ ント抜去および交換の最大の原因が結石形成であり、結石形成の 予防が留置期間の延長に寄与すると考兄られた。結論】 尿道ステ ント留置術は適応症例を選択し適切な尿路管理を行うことによ り、侵襲的治療が困難な男性尿閉症例の有用な治療法である。

\section{PP-040 原発性肺癌を合併した膀胱癌症例の検討}

\section{昭和大学横浜市北部病院}

椎木一彦, 島田誠, 井上 克己, 菅原草, 永田 将一, 押野見 和彦, 前田 智子

【対象と方法】当院で病理組織学的にそれぞれ原発腫湟と診断さ れた膀胱癌と肺癌の合併患者 5 例を選択. 患者背景や診断経緯, 組織型についてまとめる。(結果I男性 4 例，女性 1 例. 4 例は粱 煙歴あり. 膀腅癌先行 4 例, 肺癌先行 1 例. 診断経緯は先行癌の 診療の中でみつかったもの1例, 検診でみつかったもの1例, 他 の 3 例は症状を訴えて直接当該診療科を受診していた．膀腅癌 はすべて尿路上皮癌であり，筋層非浸潤例 4 例，浸潤例 1 例. 肺 癌では扁平上皮癌, 腺癌がそれぞれ 2 例. 残る1例はこれから手 術予定. 治療は膀胱癌については TUR-Bt4 例, 膀胱全摘 1 例. 肺癌については手術 3 例, 手術不能 2 例. 転帰は肺癌による癌死 2 例, 膀胱癌. 肺癌とも完治 1 例, 膀胱癌の再発, 進行なしで肺 癌進行中 1 例. [考察]癌患者の場合, 種々の検査が行われるが, この中で偶発的に他疾患がみつかることは稀ではない.しかし， 今回の検討では定期的に通院されていたにもかかわらず，後発 癌がすでに進行癌となっていた例が 5 例中 3 例あった. 膀胱癌 先行例はいずれも筋層非浸潤癌であったため, 胸部 CT 検查を 実施していなかった，一般に肺癌の予後が厳しいものであるこ とも踏まえて, 膀胱癌の経過観察に際してはたとえ完治が得ら れたものであっても特に䝟煙者や他の悪性腫瘍の既往のある者 については胸部 CT 検查は行っておくべきと考える. 